\title{
Synthesis, cytotoxic and antimicrobial activities of novel cobalt and zinc complexes of benzimidazole derivatives
}

\author{
Elif Apohan a, *, Ulku Yilmaz b, c, Ozgur Yilmaz d, Ayfer Serindag d, Hasan Küçükbay ${ }^{\text {c, ** }}$, \\ Ozfer Yesilada ${ }^{a}$, Yusuf Baran ${ }^{\text {e, }}$, \\ a Inonu University, Art and Science Faculty, Department of Biology, Malatya, Turkey \\ b Inonu University, Battalgazi Vocational School, Battalgazi, Malatya, Turkey \\ ${ }^{\mathrm{c}}$ Inonu University, Art and Science Faculty, Department of Chemistry, Malatya, Turkey \\ ${ }^{\mathrm{d}}$ Inonu University, Institute of Science, Department of Biology, Malatya, Turkey \\ e Izmir Institute of Technology, Science Faculty, Department of Molecular Biology and Genetic, Izmir, Turkey \\ ${ }^{\mathrm{f}}$ Abdullah Gul University, Faculty of Life and Natural Sciences, Molecular Biology and Genetic Kayseri, Turkey
}

\section{A R T I C L E I N F O}

\section{Article history:}

Received 5 September 2016

Received in revised form

5 November 2016

Accepted 11 November 2016

Available online 14 November 2016

\section{Keywords:}

Benzimidazole complexes

Cytotoxic

Lung cancer

Antimicrobial

\begin{abstract}
A B S T R A C T
In this study fourteen novel cobalt (II) or zinc (II) complexes of benzimidazoles were synthesized from the 1-(4-substitutedbenzyl)-1H-benzimidazoles and $\mathrm{CoCl}_{2} \cdot 6 \mathrm{H}_{2} \mathrm{O}$ or $\mathrm{ZnCl}_{2}$. Cytotoxic activities of novel complexes were investigated against lung cancer cells (A549) and BEAS-2B. Three of the examined compounds (1, 4 and $\mathbf{5}$ ) showed high cytotoxic activity against $\mathrm{A} 549$. While the $\mathrm{IC}_{50}$ of the cisplatin was $2.56 \mu \mathrm{g} / \mathrm{mL}$ for A549 cells at $72 \mathrm{~h}$, the IC 50 values of compounds $\mathbf{1}, \mathbf{4}$ and $\mathbf{5}$ were $1.97,1.87$ and $1.9 \mu \mathrm{g} / \mathrm{mL}$, respectively. $\mathrm{IC}_{50}$ values of these compounds for BEAS-2B cells were higher than the $\mathrm{IC}_{50}$ values for A549. While the $\mathrm{IC}_{50}$ values for BEAS-2B cells were $59.8,24.5$ and $32.67 \mu \mathrm{g} / \mathrm{mL}$, respectively, the $\mathrm{IC}_{50}$ of the cisplatin was determined as $2.53 \mu \mathrm{g} / \mathrm{mL}$ in the present work. Three of the compounds have also high antimicrobial activity against all the microorganisms used.
\end{abstract}

(c) 2016 Elsevier B.V. All rights reserved.

\section{Introduction}

Benzimidazole derivatives are interesting heterocycles because they are present in many naturally occurring products and various drugs. They also an important pharmacophore in modern drug discovery and continue to be the most versatile class of compounds possessing different pharmacological activities such as antitumor [1-3], antiulcer [4,5], antifungal [6,7], antibacterial [8-10], antihelmintic [11], anti-inflammatory [12-14], anticonvulsant [15], antitubercular [16-18], antidepressant [19], antihypertensive [20,21], anticoagulant [22] and antiviral [23,24].

Moreover, benzimidazole is of a considerable interest as a ligand toward transition metal ions with a variety of biological molecules including ionheme systems, vitamin $\mathrm{B}_{12}$ and its derivatives, and several metalloproteins. For this reason, the complexes of transition metal salts with benzimidazole derivatives have been extensively

\footnotetext{
* Corresponding author.

** Corresponding author.

E-mail addresses: elif.apohan@inonu.edu.tr (E. Apohan), hasan.kucukbay@ inonu.edu.tr (H. Küçükbay).
}

studied as a model structure of some important biological molecules. Metal complexes of biological important ligands are sometimes more active than free ligands [25]. It has been reported that the transition metal complexes with a ligand containing benzimidazole bearing trimethylsilylpropyl exhibit high antitumor activity [26]. Among the cancer types, lung cancer is a common cause of cancer-related death worldwide [27]. It is responsible from 1.3 million deaths annually across the world. In Turkey, the agestandardized incidence of lung cancer was found to be 75.8/ 100,000 population in men and $9.6 / 100,000$ population in women [28]. Its incidence and mortality is $52.5 / 100,000$ and $48.7 / 100,000$ per year in the world, respectively [29]. Lung cancer is heterogeneous and consists of small cell lung cancer (SCLC) and non-small cell lung cancer (NSCLC) [30]. The most common subtype NSCLC is responsible from nearly 80 to $90 \%$ of all lung cancers [29,31-33]. Despite novel molecular therapies, the 5-year relative survival rate of patients diagnosed with NSCLC is only 17\% [29,32,34]. Conventional treatments of NSCLC are fairly ineffective [31]. Chemotherapy resistance is one of the main reasons leading to the failure of chemotherapy [35]. Therefore, there is an urgent need for novel drugs with an improved efficacy against NSCLC. 
In our previous works, some benzimidazole metal (cobalt(II), cooper (II), iron (II), nickel (II) and zinc (II)) complexes have been synthesized successfully and their physical and spectroscopic properties including single crystal $\mathrm{x}$-ray analysis results reported [36-38]. More recently, antitumor properties of some benzimidazolium ligands were determined and promising results obtained [39].

According to the literature knowledge and our previous studies [36-40], in this study it was aimed to synthesized new cobalt(II) and zinc(II) complexes incorporating benzyl-substituted benzimidazole complexes (Scheme 1) in attempt to obtain possible active compounds having cytotoxic activities against cancer cell lines A549 and BEAS-2B and antimicrobial activities against Gram positive ( $S$. aureus and E. faceium) and Gram negative bacteria (E. coli and $P$. aeruginosa) and a yeast, Candida albicans.

\section{Experimental}

The starting materials and reagents used in the reactions were supplied commercially by Acros, Aldrich or Merck Chemical Co. ${ }^{1} \mathrm{H}$ NMR (300.13 MHz) and ${ }^{13} \mathrm{C}$ NMR $(75.47 \mathrm{MHz})$ spectra were recorded using a Bruker Avance $300 \mathrm{MHz}$ Ultrashield high performance digital FT NMR spectrometer. Infrared spectra were recorded using an ATR unit from on a Perkin-Elmer FT-IR spectrophotometer. UVVis spectra were measured on a Perkin-Elmer Lambda 35 spectrophotometer. Elemental analyses were performed with a LECO CHNS-932 elemental analyzer. Melting points were recorded using an electrothermal-9200 melting point apparatus and are uncorrected.

1-(4-Chlorobenzyl)-1H-benzimidazole (I), 1-(4-bromobenzyl)$1 H$-benzimidazole (II), 1-(4-tolylbenzyl)-1H-benzimidazole (III), 1 (4-cyanobenzyl)-1H-benzimidazole (IV), 1-(4-methoxybenzyl)- $1 \mathrm{H}$ benzimidazole $(\mathbf{V})$, 1-(4-nitrobenzyl)-1H-benzimidazole (VI), 1-(4vinylbenzyl)-1H-benzimidazole (VII) were synthesized according to the literature procedures [41-46]. Compounds (1-14) were synthesized from 1-(4-substitutedbenzyl)-1H-benzimidazole with $\mathrm{ZnCl}_{2}$ and $\mathrm{CoCl}_{2} \times 6 \mathrm{H}_{2} \mathrm{O}$ in $\mathrm{EtOH}$ (Scheme 1 ).

\subsection{Synthesis}

\subsubsection{Synthesis of dichlorobis[1-(4-chlorobenzyl)-1H-}

benzimidazole ${ }_{K} N^{3}$ ]zinc (II), (1)

A mixture of 1-(4-chlorobenzyl)-1H-benzimidazole (2.00 g, $8.24 \mathrm{mmol}), \mathrm{ZnCl}_{2}(0.56 \mathrm{~g}, 4.12 \mathrm{mmol})$ and $\mathrm{EtOH}(20 \mathrm{~mL})$ was heated under reflux for $4 \mathrm{~h}$ and then the mixture was cooled to room temperature and filtered off. White colored solid was crystallized with DMF/EtOH (1:2) $(10 \mathrm{~mL})$. White crystals of the title compound were washed with diethyl ether $/ n$-hexane $(1: 1)$ and dried under ambient atmosphere. Yield: 2.25 g, 88\%, m.p.: 257-258 ${ }^{\circ} \mathrm{C}$. Anal. Calcd for $\mathrm{C}_{28} \mathrm{H}_{22} \mathrm{Cl}_{4} \mathrm{~N}_{4} \mathrm{Zn}(\%)$ : C, 54.09; $\mathrm{H}, 3.57 ; \mathrm{N}, 9.01$. Found (\%): C, 53.96; H, 3.63; N, 8.89. IR: $\left.v_{(\mathrm{C}}=\mathrm{N}\right): 1489 \mathrm{~cm}^{-1} .{ }^{1} \mathrm{H}$ NMR (DMSO- $d_{6}$, $300 \mathrm{MHz}$ ): $\delta 5,65\left(\mathrm{~s}, 4 \mathrm{H}, \mathrm{CH}_{2}\right), 7.28-7.43(\mathrm{~m}, 12 \mathrm{H}, \mathrm{Ar}-\mathrm{H}), 7.61-7.67$ (m, 2H, Ar-H), 7.84-7.90 (m, 2H, Ar-H), 8.90 (s, 2H, NCHN). ${ }^{13} \mathrm{C} \mathrm{NMR}$ (DMSO- $\left.d_{6}, 75.5 \mathrm{MHz}\right): \delta 47.9\left(\mathrm{CH}_{2}\right), 112.2,118.9,123.8,124.3,129.3$, 130.0, 133.2, 133.3, 135.5, 140.8 (Ar-C), 145.5 (NCHN) ppm.

Similarly, the compounds of $3,5,7,9,11$ and 13 were obtained by the reaction of 1-(4-bromobenzyl)-1H-benzimidazole, 1-(4tolylbenzyl)- $1 H$-benzimidazole, 1 -(4-cyanobenzyl)-1H-benzimidazole, 1-(4-methoxybenzyl)-1H-benzimidazole, 1-(4-nitrobenzyl)$1 H$-benzimidazole, 1-(4-vinylbenzyl)-1H-benzimidazole with $\mathrm{ZnCl}_{2}$ and 2, 4, 6, 8, 10, 12 and 14 with $\mathrm{CoCl}_{2} \times 6 \mathrm{H}_{2} \mathrm{O}$, respectively.

\subsubsection{Dichlorobis[1-(4-clorobenzyl)-1H-benzimidazole $\left.{ }_{K} \mathrm{~N}^{3}\right]$ cobalt} (II), (2)

Yield: $2.28 \mathrm{~g}$ (blue crystals), $90 \%$, m.p.: $254-255^{\circ} \mathrm{C}$. Anal. Calcd for $\mathrm{C}_{28} \mathrm{H}_{22} \mathrm{Cl}_{4} \mathrm{~N}_{4} \mathrm{Co}(\%)$ : C, 54.66; H, 3.60; N, 9.11. Found (\%): C, 53.90; H, 3.57; N, 8.83. IR: $v_{(\mathrm{C}=\mathrm{N})}: 1489 \mathrm{~cm}^{-1}$.

\subsubsection{Dichlorobis[1-(4-bromobenzyl)-1H-benzimidazole- $\left.{ }_{K} N^{3}\right] z i n c$ (II), (3)}

Yield: $2.26 \mathrm{~g}$ (white crystals), $91 \%$, m.p.: $263-264{ }^{\circ} \mathrm{C}$. Anal. Calcd for $\mathrm{C}_{28} \mathrm{H}_{22} \mathrm{Br}_{2} \mathrm{Cl}_{2} \mathrm{~N}_{4} \mathrm{Zn}(\%): \mathrm{C}, 47.32 ; \mathrm{H}, 3.12 ; \mathrm{N}, 7.88$. Found (\%): C, 47.20; H, 3.08; N, 7.92. IR: $v_{(\mathrm{C}=}={ }_{\mathrm{N})}: 1491 \mathrm{~cm}^{-1} .{ }^{1} \mathrm{H}$ NMR (DMSO- $d_{6}$, $300 \mathrm{MHz}$ ): $\delta$ 5,61 (s, 4H, $\left.\mathrm{CH}_{2}\right), 7.27-7.35(\mathrm{~m}, 8 \mathrm{H}, \mathrm{Ar}-\mathrm{H}), 7.53-7.64$ (m, 6H, Ar-H), 7.82-7.86 (m, 2H, Ar-H), 8.80 (s, 2H, NCHN). ${ }^{13} \mathrm{C}$ NMR (DMSO- $\left.d_{6}, 75.5 \mathrm{MHz}\right): \delta 47.9\left(\mathrm{CH}_{2}\right), 112.0,119.1,121.7,123.5,124.1$, 130.3, 132.2, 133.4, 136.1, 141.3 (Ar-C), 145.3 (NCHN) ppm.

\subsubsection{Dichlorobis[1-(4-bromobenzyl)-1H-benzimidazole- $\left.{ }_{K} N^{3}\right]$} cobalt (II), (4)

Yield: $2.14 \mathrm{~g}$ (blue crystals), $87 \%$, m.p.: $262-263{ }^{\circ} \mathrm{C}$. Anal. Calcd for $\mathrm{C}_{28} \mathrm{H}_{22} \mathrm{Br}_{2} \mathrm{Cl}_{2} \mathrm{~N}_{4} \mathrm{Co}$ (\%): C, 47.76; $\mathrm{H}, 3.15 ; \mathrm{N}, 7.96$. Found (\%): C, 47.07; H, 3.20; N, 7.73. IR: $v_{(\mathrm{C}}={ }_{\mathrm{N})}: 1491 \mathrm{~cm}^{-1}$.

\subsubsection{Dichlorobis[1-(4-tolylbenzyl)-1H-benzimidazole $\left.{ }_{\mathrm{K}} \mathrm{N}^{3}\right]$ zinc (II),} (5)

Yield: $2.13 \mathrm{~g}$ (white crystals), $82 \%$, m.p.: $238-239{ }^{\circ} \mathrm{C}$. Anal. Calcd for $\mathrm{C}_{30} \mathrm{H}_{28} \mathrm{Cl}_{2} \mathrm{~N}_{4} \mathrm{Zn}(\%)$ : C, 62.03; $\mathrm{H}, 4.86 ; \mathrm{N}, 9.64$. Found (\%): C, 61.27; $\mathrm{H}, 4.91 ; \mathrm{N}, 9.62$. IR: $\left.v_{(\mathrm{C}}={ }_{\mathrm{N}}\right): 1483 \mathrm{~cm}^{-1} .{ }^{1} \mathrm{H}$ NMR (DMSO- $d_{6}$, $300 \mathrm{MHz}): \delta 2.25\left(\mathrm{~s}, 6 \mathrm{H}, \mathrm{CH}_{3}\right)$ 5,57 (s, 4H, $\left.\mathrm{CH}_{2}\right), 7.13-7.32(\mathrm{~m}, 12 \mathrm{H}$,

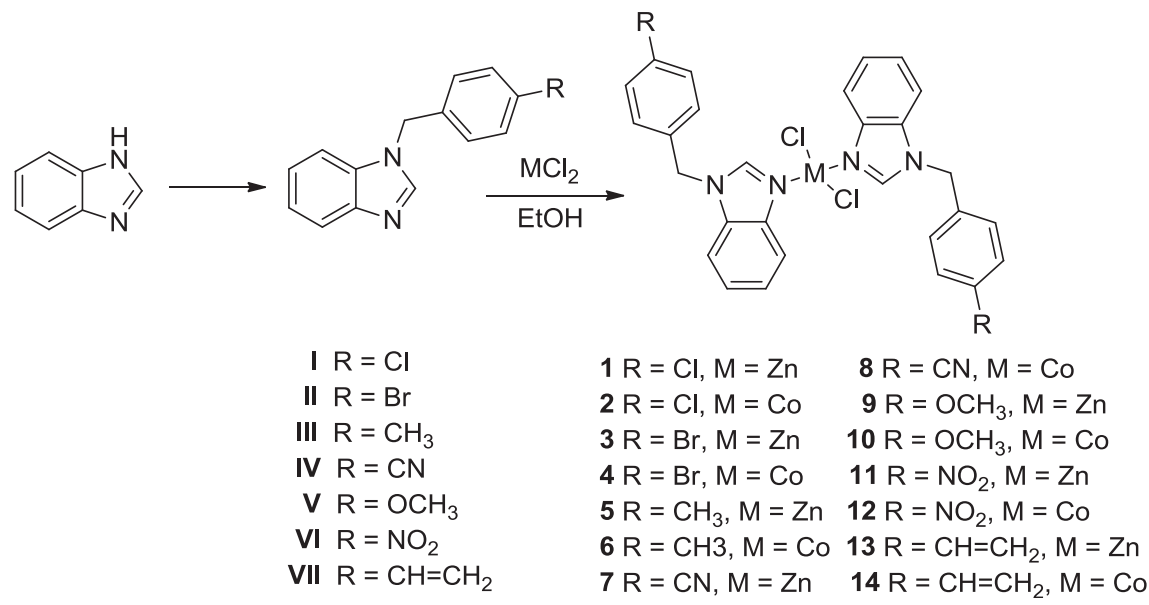

Scheme 1. Synthesis pathways of the benzimidazole complexes. 
Ar-H), 7.61-7.64 (m, 2H, Ar-H), 7.82-7.85 (m, 2H, Ar-H), 8.81 (s, 2H, NCHN). ${ }^{13} \mathrm{C}$ NMR (DMSO- $\left.d_{6}, 75.5 \mathrm{MHz}\right): \delta 21.1\left(\mathrm{CH}_{3}\right), 48.5\left(\mathrm{CH}_{2}\right)$, 112.2, 118.9, 123.6, 124.1, 128.1, 129.8, 133.4, 133.5, 137.8, 140.9 (ArC), 145.3 ( NCHN) ppm.

\subsubsection{Dichlorobis[1-(4-tolylbenzyl)-1H-benzimidazole- $\left.{ }_{K} N^{3}\right]$ cobalt (II), (6)}

Yield: $2.20 \mathrm{~g}$ (blue crystals), $85 \%$, m.p.: $235-236{ }^{\circ} \mathrm{C}$. Anal. Calcd for $\mathrm{C}_{30} \mathrm{H}_{28} \mathrm{Cl}_{2} \mathrm{~N}_{4} \mathrm{Co}(\%)$ : C, 62.73; $\mathrm{H}, 4.91 ; \mathrm{N}, 9.75$. Found (\%): C, 61.74; H, 4.84; N, 9.59. IR: $\left.v_{(\mathrm{C}}=\mathrm{N}\right): 1483 \mathrm{~cm}^{-1}$.

\subsubsection{Dichlorobis[1-(4-cyanobenzyl)-1H-benzimidazole- $\left.{ }_{K} N^{3}\right] z i n c$ (II), (7)}

Yield: $2.35 \mathrm{~g}$ (white crystals), $91 \%$, m.p.: $213-214{ }^{\circ} \mathrm{C}$. Anal. Calcd for $\mathrm{C}_{30} \mathrm{H}_{22} \mathrm{Cl}_{2} \mathrm{~N}_{6} \mathrm{Zn}$ (\%): C, 59.77; $\mathrm{H}, 3.68 ; \mathrm{N}, 13.94$. Found (\%): $\mathrm{C}$, 59.62; H, 3.63; N, 13.81. IR: $v_{(\mathrm{C}}={ }_{\mathrm{N})}: 1482, v_{(\mathrm{C}} \equiv_{\mathrm{N})}: 2233 \mathrm{~cm}^{-1} \cdot{ }^{1} \mathrm{H}$ NMR (DMSO- $\left.d_{6}, 300 \mathrm{MHz}\right): \delta 5,73\left(\mathrm{~s}, 4 \mathrm{H}, \mathrm{CH}_{2}\right), 7.29-7.85(\mathrm{~m}, 16 \mathrm{H}$, Ar-H), 8.78 (s, 2H, NCHN). ${ }^{13} \mathrm{C}$ NMR (DMSO-d, $75.5 \mathrm{MHz}$ ): $\delta 47.6$ $\left(\mathrm{CH}_{2}\right), 110.7(\mathrm{CN}), 111.4,118.5,118.7,123.2,123.7,128.3,132.7,132.9$, 140.7, 141.7 (Ar-C), 145.0 (NCHN) ppm.

\subsubsection{Dichlorobis[1-(4-cyanobenzyl)-1H-benzimidazole- $\left.{ }_{K} N^{3}\right]$ cobalt (II), (8)}

Yield: $2.40 \mathrm{~g}$ (blue crystals), $94 \%$, m.p.: $198-200{ }^{\circ} \mathrm{C}$. Anal. Calcd for $\mathrm{C}_{30} \mathrm{H}_{22} \mathrm{Cl}_{2} \mathrm{~N}_{6} \mathrm{Co}(\%): \mathrm{C}, 60.42 ; \mathrm{H}, 3.72 ; \mathrm{N}, 14.09$. Found (\%): $\mathrm{C}$, 60.68; H, 3.98; N, 13.53. IR: $\left.v_{(\mathrm{C}}=\mathrm{N}\right): 1482, v_{(\mathrm{C}} \equiv_{\mathrm{N})}: 2233 \mathrm{~cm}^{-1}$.

\subsubsection{Dichlorobis[1-(4-methoxybenzyl)-1H-benzimidazole- $\left.{ }_{K} N^{3}\right]$ zinc (II), (9)}

Yield: $2.30 \mathrm{~g}$ (white crystals), 90\%, m.p.: $210-212{ }^{\circ} \mathrm{C}$. Anal. Calcd for $\mathrm{C}_{30} \mathrm{H}_{28} \mathrm{Cl}_{2} \mathrm{~N}_{4} \mathrm{O}_{2} \mathrm{Zn}(\%): \mathrm{C}, 58.79 ; \mathrm{H}, 4.60 ; \mathrm{N}, 9.14$. Found (\%): $\mathrm{C}$, 57.47; H, 4.28; N, 8.75. IR: $\left.v_{(\mathrm{C}}=\mathrm{N}\right): 1485 \mathrm{~cm}^{-1}$. ${ }^{1} \mathrm{H}$ NMR (DMSO- $d_{6}$, $300 \mathrm{MHz}): \delta 3.70\left(\mathrm{~s}, 6 \mathrm{H}, \mathrm{OCH}_{3}\right) 5.54\left(\mathrm{~s}, 4 \mathrm{H}, \mathrm{CH}_{2}\right), 6.90(\mathrm{~d}, 4 \mathrm{H}$, $J=6.6 \mathrm{~Hz}, \mathrm{Ar}-\mathrm{H}), 7.28-7.36$ (m, 8H, Ar-H), 7.65-7.68 (m, 2H, Ar-H), 7.82-7.85 (m, 2H, Ar-H), 8.80 (s, 2H, NCHN). ${ }^{13} \mathrm{C}$ NMR (DMSO-d $d_{6}$, $75.5 \mathrm{MHz}): \delta 47.7\left(\mathrm{OCH}_{3}\right), 55.0\left(\mathrm{CH}_{2}\right), 111.7,114.1,118.4,123.0,123.5$, 127.9, 129.2, 132.8, 140.5, 158.9 (Ar-C), 144.1 (NCHN) ppm.

\subsubsection{Dichlorobis[1-(4-methoxybenzyl)-1H-benzimidazole- ${ }_{K} N^{3}$ ] cobalt (II), (10)}

Yield: $2.23 \mathrm{~g}$ (blue crystals), 87\%, m.p.: $208-209{ }^{\circ} \mathrm{C}$. Anal. Calcd for $\mathrm{C}_{30} \mathrm{H}_{28} \mathrm{Cl}_{2} \mathrm{~N}_{4} \mathrm{O}_{2} \mathrm{Co}$ (\%): C, 59.42; $\mathrm{H}, 4.65 ; \mathrm{N}, 9.24$. Found (\%): $\mathrm{C}$, 58.90; H, 4.55; N, 9.17. IR: $\left.v_{(\mathrm{C}}=\mathrm{N}\right): 1485 \mathrm{~cm}^{-1}$.

\subsubsection{Dichlorobis[1-(4-nitrobenzyl)-1H-benzimidazole- $\left.{ }_{K} N^{3}\right] z i n c$ (II), (11)}

Yield: 2.16 g (yellow crystals), 85\%, m.p.: $303-304{ }^{\circ} \mathrm{C}$. Anal. Calcd for $\mathrm{C}_{28} \mathrm{H}_{22} \mathrm{Cl}_{2} \mathrm{~N}_{6} \mathrm{O}_{4} \mathrm{Zn}(\%)$ : C, 52.32; $\mathrm{H}, 3.45 ; \mathrm{N}, 13.07$. Found (\%): C, 52.04; H, 3.31; N, 12.89. IR: $v_{(\mathrm{C}}={ }_{\mathrm{N})}: 1483 \mathrm{~cm}^{-1} .{ }^{1} \mathrm{H}$ NMR (DMSO- $\left.d_{6}, 300 \mathrm{MHz}\right): \delta 5,81\left(\mathrm{~s}, 4 \mathrm{H}, \mathrm{CH}_{2}\right), 7.29-7.35(\mathrm{~m}, 4 \mathrm{H}, \mathrm{Ar}-\mathrm{H})$, 7.53-7.62 (m, 6H, Ar-H), 7.87-7.90 (m, 2H, Ar-H), 8.17-8.22 (m, 4H, Ar-H), 8.90 (s, 2H, NCHN). ${ }^{13} \mathrm{C}$ NMR (DMSO-d, $\left.75.5 \mathrm{MHz}\right): \delta 47.4$ $\left(\mathrm{CH}_{2}\right), 111.5,118.6,123.3,123.8,123.9,128.6,132.8,140.5,143.6,147.1$ (Ar-C), 145.1 (NCHN) ppm.

\subsubsection{Dichlorobis[1-(4-nitrobenzyl)-1H-benzimidazole- $\left.{ }_{K} N^{3}\right]$ cobalt} (II), (12)

Yield:2.05 g (green crystals), 82\%, m.p.: $300-301{ }^{\circ} \mathrm{C}$. Anal. Calcd for $\mathrm{C}_{28} \mathrm{H}_{22} \mathrm{Cl}_{2} \mathrm{~N}_{6} \mathrm{O}_{4} \mathrm{Co}(\%)$ : C, 52.85; H, 3.48; N, 13.21. Found (\%): C, 52.45; H, 3.26; N, 13.14. IR: $v_{(\mathrm{C}}={ }_{\mathrm{N})}: 1482 \mathrm{~cm}^{-1}$.

\subsubsection{Dichlorobis[1-(4-vinylbenzyl)-1H-benzimidazole $\left.{ }_{-} \mathrm{N}^{3}\right] z i n c$} (II), (13)

Yield: $2.06 \mathrm{~g}$ (white crystals), $80 \%$, m.p.: $>350{ }^{\circ} \mathrm{C}$. Anal. Calcd for $\mathrm{C}_{32} \mathrm{H}_{28} \mathrm{Cl}_{2} \mathrm{~N}_{4} \mathrm{Zn}(\%)$ : C, 63.54; H, 4.67; N, 9.26. Found (\%): C, 63.14; H,
4.58; N, 9.05. IR: $v_{(\mathrm{C}=\mathrm{N})}: 1484 \mathrm{~cm}^{-1}$. ${ }^{1} \mathrm{H}$ NMR (DMSO- $d_{6}, 300 \mathrm{MHz}$ ): $\delta 5.25\left(\mathrm{dd}, 2 \mathrm{H},{ }^{3} J_{\text {cis }}=10.8,{ }^{2} J_{\text {gem }}=0.9 \mathrm{~Hz}, \mathrm{CH}=\mathrm{CH}_{2}\right), 5.61(\mathrm{~s}, 4 \mathrm{H}$, $\left.\mathrm{CH}_{2}\right), 5.80\left(\mathrm{dd}, 2 \mathrm{H},{ }^{3} J_{\text {trans }}=17.7,{ }^{2} J_{\text {gem }}=0.9 \mathrm{~Hz}, \mathrm{CH}=\mathrm{CH}_{2}\right), 6.69(\mathrm{dd}$, $\left.2 \mathrm{H},{ }^{3} J_{\text {cis }}=10.8,{ }^{3} J_{\text {trans }}=17.7 \mathrm{~Hz}, \mathrm{CH}=\mathrm{CH}_{2}\right), 7.28-7.30(\overline{\mathrm{m}}, 4 \mathrm{H}, \mathrm{Ar}-\mathrm{H})$, $7.33(\mathrm{~d}, 4 \mathrm{H}, J=8.4 \mathrm{~Hz}, \mathrm{Ar}-\mathrm{H}), 7.44 \overline{(\mathrm{d}}, 4 \mathrm{H}, J=8.1 \mathrm{~Hz}, \mathrm{Ar}-\mathrm{H}), 7.61-7.64$ (m, 2H, Ar-H), 7.82-7.85 (m, 2H, Ar-H), 8.82 (s, 2H, NCHN). ${ }^{13} \mathrm{C} \mathrm{NMR}$ $\left(\mathrm{DMSO}_{6}, 75.5 \mathrm{MHz}\right): \delta 47.9\left(\mathrm{CH}_{2}\right), 111.7\left(\mathrm{CH}=\mathrm{CH}_{2}\right), 135.9(\mathrm{CH}=$ $\left.\mathrm{CH}_{2}\right), 114.8,118.4,123.2,123.7,126.5,127.9,132.9,135.6,136.8,140.4$ (Ar-C), 144.9 (NCHN) ppm.

\subsubsection{Dichlorobis[1-(4-vinylbenzyl)-1H-benzimidazole $\left.{ }_{K} N^{3}\right]$ cobalt (II), (14)}

Yield: $1.98 \mathrm{~g}$ (blue crystals), $77 \%$, m.p.: $>350{ }^{\circ} \mathrm{C}$. Anal. Calcd for $\mathrm{C}_{32} \mathrm{H}_{28} \mathrm{Cl}_{2} \mathrm{~N}_{4} \mathrm{Co}(\%): \mathrm{C}, 64.23 ; \mathrm{H}, 4.72 ; \mathrm{N}, 9.36$. Found (\%): C, 64.05; H, 4.79; N, 9.29. IR: $\left.v_{(\mathrm{C}=} \mathrm{N}\right): 1483 \mathrm{~cm}^{-1}$.

\subsection{Cell lines and culture conditions}

The human cancer lines, lung adenocarcinoma (A549) and healthy human lung bronchial epithelium cells (BEAS-2B) were used for in vitro screening experiments. A549 cells were obtained from Prof. Dr. Fikrettin Sahin (Yeditepe University, Department of Genetics and Bioengineering, Istanbul/Turkey). The cells were maintained in RPMI 1640 growth medium containing 10\% fetal bovine serum and $1 \%$ penicillin/streptomycin at $37{ }^{\circ} \mathrm{C}$ in $5 \% \mathrm{CO}_{2}$ [47].

\subsection{Drug treatment and MTT assay for cytotoxicity of compounds}

Stock solutions of the benzimidazole metal complexes were prepared in dimethylsulfoxide (DMSO) and further dilutions were made with a fresh culture medium (the concentration of DMSO in the final culture medium was $<0.1 \%$ ). Cytotoxic effects of compounds against the cells were determined by MTT cell proliferation assay. Briefly, the A549 and BEAS-2B cells were plated in 96 well plates $\left(5 \times 10^{3}\right.$ cells/well) for $24 \mathrm{~h}$ before treatment with compounds to allow the attachment of the cells to surface of the plate. They incubated at $37{ }^{\circ} \mathrm{C}$ in a humidified incubator with $5 \% \mathrm{CO}_{2}$ for 24,48 and $72 \mathrm{~h}$. Then, the tested compounds were added to obtain the final concentration in the range of $(0-100 \mu \mathrm{g} / \mathrm{mL})$ and the cells were incubated for 24,48 and $72 \mathrm{~h}$. After incubation, the cells were treated with $20 \mu \mathrm{L}$ of MTT reagent for $4 \mathrm{~h}$ at $37^{\circ} \mathrm{C}$. Then, the supernatants were removed from the plates and the MTT crystals obtained were homogenized by adding $100 \mu \mathrm{L}$ DMSO into each well. To homogenize the pellets more efficiently, the plates were shaken for $5 \mathrm{~min}$ by shaker. Afterwards, the plates were read under $570 \mathrm{~nm}$ wavelengths by Microplate reader (Versa Max Tunable) [48]. Twelve wells were used for every concentration was repeated in twelve wells and $\mathrm{IC}_{50}$ values $(\mu \mathrm{g} / \mathrm{mL})$ were defined as the compound concentrations reducing absorbance to 50\% of control values. Cisplatin was also used as a control agent.

\subsection{Microorganisms used}

The microorganisms used for testing the antibacterial and antifungal activity were Escherichia coli ATCC 25922, Staphylococcus aureus ATCC 29213, Pseudomonas aeruginosa ATCC 27853, Enterococcus faecium $\mathrm{NJ}-1$ and Candida albicans, respectively. These microorganisms are stock cultures in the Biotechnology Laboratory, Inonu University. Stock cultures of these bacteria and yeast were maintained on blood agar and sabouraud dextrose agar at $+4{ }^{\circ} \mathrm{C}$, respectively. 


\subsection{Antimicrobial activity testing}

The minimum inhibitory concentration (MIC) method was performed to test the antibacterial and antifungal activity of the newly synthesized compounds. Because dimethylsulfoxide (DMSO) has no inhibitory effect on growth of microorganisms in the concentration used, the stock solutions of the compounds were prepared by dissolving them in DMSO. The MICs of these compounds were investigated in sterile 96-well microplate by serial dilution with distilled water. The plates were incubated at $37{ }^{\circ} \mathrm{C}$ for $24 \mathrm{~h}$ under static conditions. The lowest concentration of the compounds at which no visible growth was seen was considered as the MIC.

\subsection{Statistical analysis}

Experiments were carried out for twelve wells. The results were expressed as mean \pm SD. Statistical analysis was performed using GraphPad Prism 5. The difference between two groups was analyzed by 2 way Anova and one way Anova and Nonparametric Tukey test. A difference with or $P<0.001\left(^{*}\right)$ or $P<0.05\left({ }^{* *}\right)$ was considered statistically significant.

\section{Results and discussion}

\subsection{Synthesis and characterization of the benzimidazole compounds}

The cobalt (II) and zinc (II) complexes were synthesized from the reaction of the appropriate benzimidazole ligand and metal salt. The complexes were smoothly crystallized in a DMF/EtOH mixture. The structures of $\mathrm{Zn}$ (II) benzimidazole complexes $(\mathbf{1}, \mathbf{3}, \mathbf{5}, \mathbf{7}, \mathbf{9}, 11$ and 13) were elucidated by ${ }^{1} \mathrm{H}$ NMR, ${ }^{13} \mathrm{C}$ NMR and IR spectrometric analyses. All spectral data were in agreement with the proposed structures. Due to paramagnetic properties of $\mathrm{Co}$ (II)-benzimidazole complexes $(2,4,6,8,10,12$ and 14$)$ we could not observed appropriate NMR signals even more scans in diluted solvents. For this reason, the structures of $\mathrm{Co}$ (II) benzimidazole complexes were elucidated by IR and UV-Vis spectrometric and elemental analyses. IR spectra of the compounds show that the strong $\left.v_{(\mathrm{C}}={ }_{N}\right)$ bands in free benzimidazoles at $1489-1495 \mathrm{~cm}^{-1}$ shift to $1482-1491 \mathrm{~cm}^{-1}$ for $\mathrm{Co}$ (II) and $\mathrm{Zn}$ (II) complexes. The bathochromic shift indicates the coordination of tertiary nitrogen of the ligands to Co (II) and $\mathrm{Zn}$ (II) atoms. These type of bathochromic shifts are also reported in the literature $[25,36-38,49,50]$. IR spectra of compound IV showed the $v_{(\mathrm{C}} \equiv_{\mathrm{N})}$ band at $2227 \mathrm{~cm}^{-1}$, and this band shifted to $2233 \mathrm{~cm}^{-1}$ for corresponding $\mathrm{Co}(\mathrm{II})$ and $\mathrm{Zn}(\mathrm{II})$ complexes. IR spectra of compound VI, showed absorption band at 851,1338 and $1509 \mathrm{~cm}^{-1}$ assigned to nitro group attached to 4-position of the benzyl group. The bands were observed at 858,1344 and $1515 \mathrm{~cm}^{-1}$ for the corresponding Co (II) complex (12) and 858, 1344 and $1518 \mathrm{~cm}^{-1}$ for the corresponding $\mathrm{Zn}$ (II) complex (11). The nitro group frequencies shifted slightly higher frequency after coordinating the metal atom.

The characteristic $\mathrm{CH}$ resonances for the proton at position 2 of the benzimidazole ligand of $\mathrm{Zn}$ (II) complexes $(\mathbf{1}, \mathbf{3}, \mathbf{5}, \mathbf{7 , 9}, 11$ and 13) were observed between 8.78 and $8.90 \mathrm{ppm}$.

As expected, the coordination to the $\mathrm{Zn}(\mathrm{II})$ ion shifts the ${ }^{1} \mathrm{H}$ NMR signals of the complex downfield from those of the free ligands $(\Delta \delta \approx 0.77$ - to $0.96 \mathrm{ppm}$ ) for the proton at position 2 of the benzimidazole ring. The protons of methylene in $\mathrm{Zn}$ (II) complexes were not shifted significantly to downfield $(\Delta \delta \approx 0.10-0.39 \mathrm{ppm})$.

The carbon resonances for the carbon at position 2 of the benzimidazole ligands of $\mathrm{Zn}$ (II) complexes $(\mathbf{1}, \mathbf{3}, \mathbf{5}, \mathbf{7}, \mathbf{9}, 11$ and 13) were observed between 141.1 and $145.5 \mathrm{ppm}$. The coordination to the $\mathrm{Zn}(\mathrm{II})$ ion shifts the ${ }^{13} \mathrm{C}$ NMR signals of the complex downfield from those of the free ligands ( $\Delta \delta \approx 0.9$ - to $2.1 \mathrm{ppm}$ ) for the carbon at position 2 of benzimidazole ring. All other aliphatic and aromatic protons and carbons were observed at expected regions.

The UV-Vis spectra of free benzimidazoles (I-VII) and its complexes (1-14) were determined in 190-800 nm region in DMSO. Free substituted benzimidazoles have absorption maxima at $273,5 \mathrm{~nm}$ attributed $n-\pi^{*}$ transitions. In the complexes, these peaks are shifted to $276.5 \mathrm{~nm}$ for the $\mathrm{Zn}$ complexes and observed same value $(273.5 \mathrm{~nm})$ for the Co complexes. The DMSO- $d_{6}$ bands for all cobalt (II) complexes $(2,4,6,8,10,12$ and 14) were observed as $666.5 \mathrm{~nm}\left(\epsilon=219.3 \mathrm{M}^{-1} \mathrm{~cm}^{-1}\right)$. All the cobalt (II) complexes showed a single DMSO- $d_{6}$ band. Since zinc (II) has no unpaired delectrons, no absorption peak was observed in the visible region for these complexes.

\subsection{Biological activity}

\subsubsection{Cytotoxicity studies}

In order to investigate the cytotoxic effects of newly synthesized cobalt (II) and zinc (II) benzimidazole complexes on A549 and BEAS-2B cells, respective cells were incubated with increasing concentrations $(0-100 \mu \mathrm{g} / \mathrm{mL})$ of compounds for 24,48 and $72 \mathrm{~h}$, and then subjected to a MTT assay. Table 1 shows the $\mathrm{IC}_{50}$ (concentration required to inhibit tumor cell proliferation by 50\%) of the compounds. Among the 14 compounds tested, compounds 1, 4 and 5 had the highest cytotoxic activity while the $\mathrm{IC}_{50}$ values of compounds $\mathbf{1}, \mathbf{4}$ and $\mathbf{5}$ were $1.97,1.87$ and $1.9 \mu \mathrm{g} / \mathrm{mL}$, respectively. This value was $2.56 \mu \mathrm{g} / \mathrm{mL}$ for cisplatin. The compounds $\mathbf{3}, \mathbf{7}, \mathbf{8}, \mathbf{9}, \mathbf{1 0}, \mathbf{1 1}$, 12,13 and 14 showed lower cytotoxic activity with $\mathrm{IC}_{50}$ values between 9 and $85 \mu \mathrm{g} / \mathrm{mL}$. The remaining two compounds 2 and $\mathbf{6}$ showed the least cytotoxic activity with $\mathrm{IC}_{50}$ higher than $100 \mu \mathrm{g} / \mathrm{mL}$ (Table 1 and Fig. 1 A, B, C, D). According to the results of $72 \mathrm{~h}$ incubation it could be stated that the compound 4 containing 4bromobenzyl substituent at the position 1 of benzimidazole ligand was more cytotoxic than the compound 1 containing 4chlorobenzyl and compound $\mathbf{5}$ containing 4-methylbenzyl substituents on A549 cells. Among the tested 14 complexes, incorporating zinc(II) metal $(\mathbf{1}, \mathbf{3}, \mathbf{5}, \mathbf{7}, \mathbf{9}, \mathbf{1 1}$ and 13) showed more cytotoxicity on A549 cells than the other compounds tested except compound 4. Compound 4 containing cobalt (II) had also high

Table 1

$\mathrm{IC}_{50}(\mu \mathrm{g} / \mathrm{mL})$ values of benzimidazole - $\mathrm{Co}(\mathrm{II})$ and $\mathrm{Zn}(\mathrm{II})$ complexes on A549 cells and BEAS-2B cells.

\begin{tabular}{|c|c|c|c|c|c|c|}
\hline \multirow[t]{3}{*}{ Compounds } & \multicolumn{6}{|c|}{ Time (hour) } \\
\hline & \multicolumn{2}{|l|}{24} & \multicolumn{2}{|l|}{48} & \multicolumn{2}{|l|}{72} \\
\hline & A549 & BEAS2B & A549 & BEAS2B & A549 & BEAS2B \\
\hline 1 & $>100$ & 65,67 & 27,84 & 59,77 & 1,97 & 59,8 \\
\hline 2 & $>100$ & 71,69 & $>100$ & 51,65 & $>100$ & 42,23 \\
\hline 3 & $>100$ & 62,95 & $>100$ & 67 & 13,77 & 61,59 \\
\hline 4 & $>100$ & 40,54 & $>100$ & 28,57 & 1,87 & 24,5 \\
\hline 5 & 50,98 & 37,81 & 15,02 & 33,35 & 1,9 & 32,67 \\
\hline 6 & 94,18 & 83,5 & 98,52 & 42,18 & $>100$ & 1,99 \\
\hline 7 & 74,87 & 58,85 & 42,68 & 53,47 & 9,36 & 51,55 \\
\hline 8 & 90,67 & 39,78 & 23,94 & 20,76 & 13,11 & 12,00 \\
\hline 9 & $>100$ & 41,22 & 89,01 & 38,70 & 28,55 & 38,24 \\
\hline 10 & $>100$ & 82,26 & $>100$ & 62,83 & 36,74 & 44,66 \\
\hline 11 & $>100$ & 81,71 & 82,36 & 67,91 & 22,36 & 60,04 \\
\hline 12 & $>100$ & $>100$ & 76,81 & $>100$ & 37,82 & 97,24 \\
\hline 13 & $>100$ & $>100$ & 88,73 & $>100$ & 77,46 & $>100$ \\
\hline 14 & $>100$ & 91,54 & $>100$ & 84,31 & 85,07 & 57,1 \\
\hline Cisplatin & 4,44 & 3,17 & 2,72 & 2,60 & 2,56 & 2.53 \\
\hline
\end{tabular}

Results are averages of twelve independent experiments.

The compounds (1,4 and $\mathbf{5})$ showed high cytotoxic activity than cisplatin against A549 whereas the same compounds showed less cytotoxic activityple against BEAS-2B. 
A
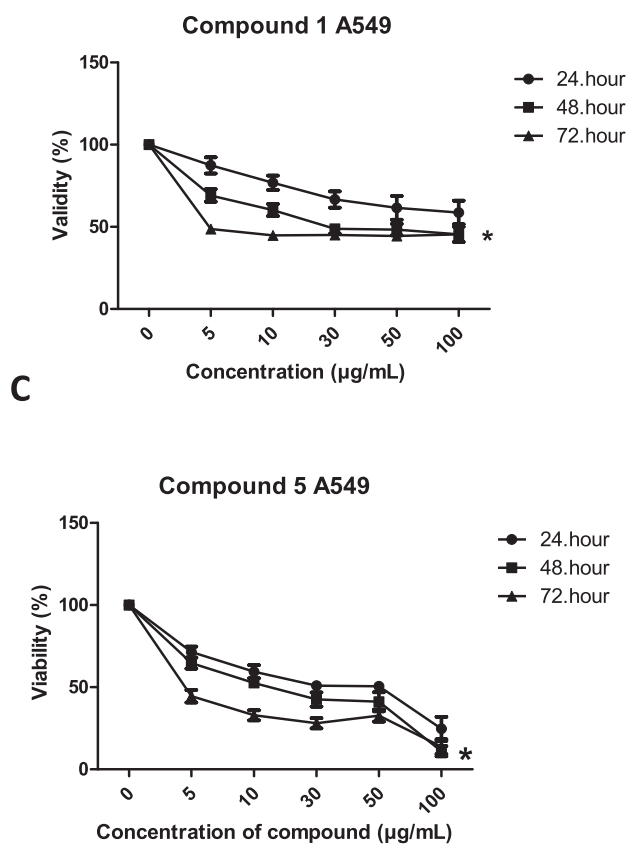

E

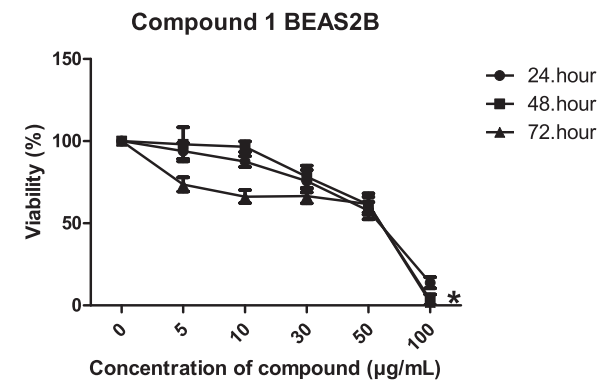

G

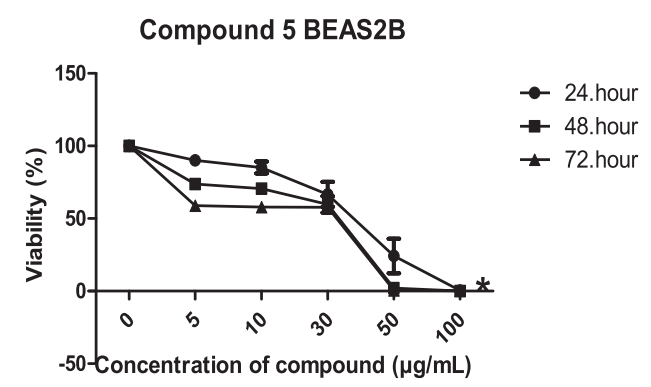

B
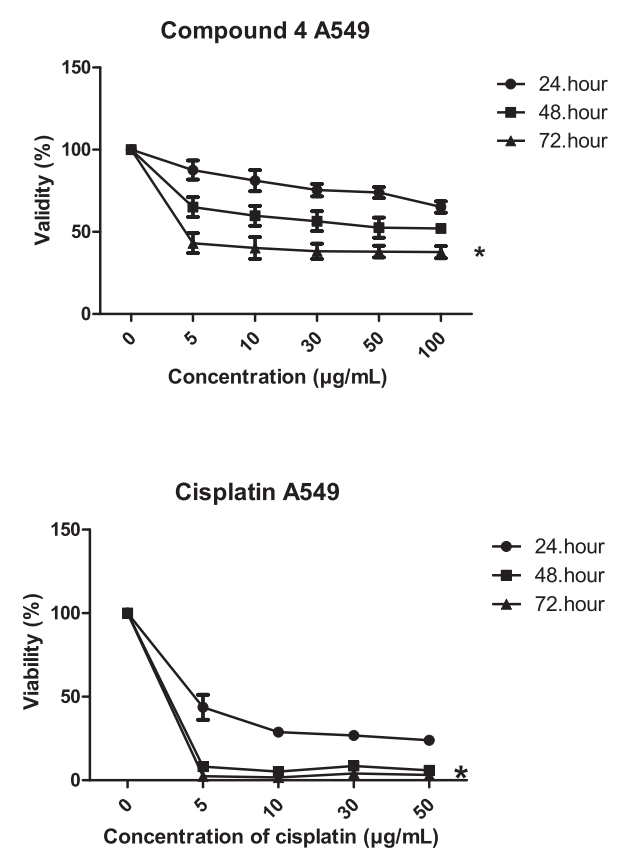

$\mathbf{F}$

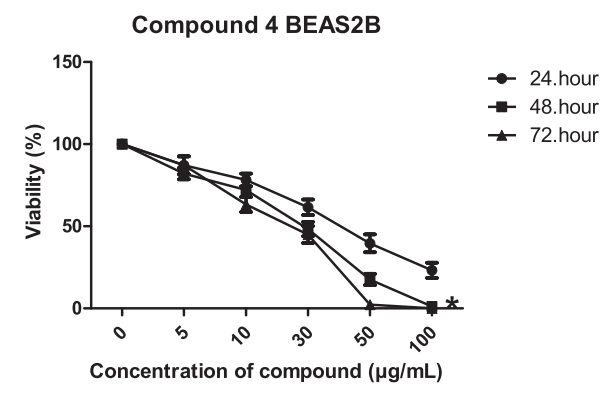

H

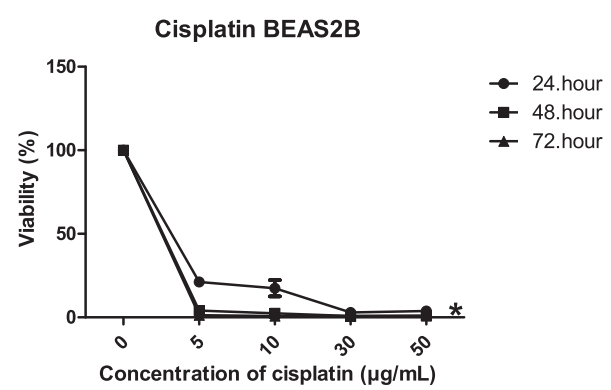

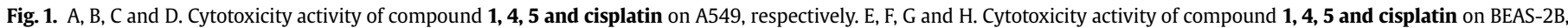
respectively. Data points represent means for experiment ${ }_{ \pm} \mathrm{SD}$ of twelve independent wells. 72 . h significantly different from respective 24 and 48 h: ${ }^{*} p<0.001$.

cytotoxic activity on A549 cells. Yurttas et al. evaluated the anticancer activity of some new1-(2-aryl-2-oxoethyl)-2-[(morpholine4-yl)thioxomethyl]benzimidazole derivatives on C6, MCF7 and
A549 cell lines and reported the $\mathrm{IC}_{50}$ values for 1-(4-chloropheny)2-(2-(morpholine-4-carbonothioyl)- $1 H$-benzo[d]imidazol-1-yl) ethanone and cisplatin, against A549 cells at $24 \mathrm{~h}$, as $15.66 \mu \mathrm{g} / \mathrm{mL}$ 
and $19 \mu \mathrm{g} / \mathrm{mL}$, respectively [51]. In our study, $\mathrm{IC}_{50}$ of the cisplatin was detected as $4.44 \mu \mathrm{g} / \mathrm{mL}$. Liu et al. suggested that $\mathrm{Zn}$ (II) complexes containing bis-benzimidazole derivatives could be candidate for further evaluation as chemotherapeutic agent for human cancers [52]. It was found that one of the new benzimidazole derivative was the most cytotoxic against A549 cells at hypoxic conditions [53].

The cytotoxicity of compounds against human lung bronchial epithelium cells was also examined. $\mathrm{IC}_{50}$ values of compounds $\mathbf{1}, \mathbf{4}$ and 5 on BEAS-2B were determined as $59.8,24.5$ and $32.67 \mu \mathrm{g} / \mathrm{mL}$, respectively. This value was $2.53 \mu \mathrm{g} / \mathrm{mL}$ for cisplatin (Table 1 and Fig. 1E, F, G, H). In order to confirm the results, A549 and BEAS-2B cells lines were treated with compounds $\mathbf{1}, \mathbf{4}$ and $\mathbf{5}$ and cisplatin for $72 \mathrm{~h}$ at concentration $3 \mu \mathrm{g} / \mathrm{mL}$. These compounds showed toxic effect against A549 cells as much as cisplatin, but they were less toxic than cisplatin on BEAS-2B (Figs. 2 and 3). Liu et al. evaluated the anticancer activities of two Zinc(II) complexes containing bisbenzimidazole derivatives and cisplatin against five cancer and one normal cell lines. They reported that complex 2 demonstrated higher growth inhibition on MCF-7 human breast carcinoma cells than cisplatin. The complexes possessed high selectivity between human cancer and normal cells (HK-2), in comparison with cisplatin [52].

\subsubsection{Antimicrobial studies}

The antibacterial and antifungal activities of these newly synthesized compounds were tested by MIC method. Antimicrobial activity results of the complexes were given in Table 2 with standard reference compounds ciprofloxacin and gentamicin. Grampositive and Gram-negative bacteria have different cell wall structure. While Gram-positive bacteria have a cell wall containing thick peptidoglycan the Gram-negative bacteria have a thin layer of peptidoglycan and also the additional outer membrane. Therefore, this outer membrane is an additional protective barrier against chemicals such as antimicrobials [54,55]. The compounds tested in this work showed antibacterial activity against all the bacteria and the yeast used. All of the compounds showed high antibacterial activity against Gram-positive bacterium $S$. aureus $(6.25 \mu \mathrm{g} / \mathrm{mL})$ but poor antibacterial activity against Gram-negative $P$. aeruginosa $(200-400 \mu \mathrm{g} / \mathrm{mL})$. While the compounds of $1,4,5,13$ and 14 showed high antibacterial activity $(25-50 \mu \mathrm{g} / \mathrm{mL})$ against Gramnegative $E$. coli, the others showed moderate activity $(100-200 \mu \mathrm{g} / \mathrm{mL})$ against this bacterium. Among the compounds used 1, 4 and 5 showed high antibacterial activity against Grampositive E. faecium. These three compounds were also effective antifungal compounds against $C$. albicans. The position and type of the substituent on the benzimidazole ring give different biological

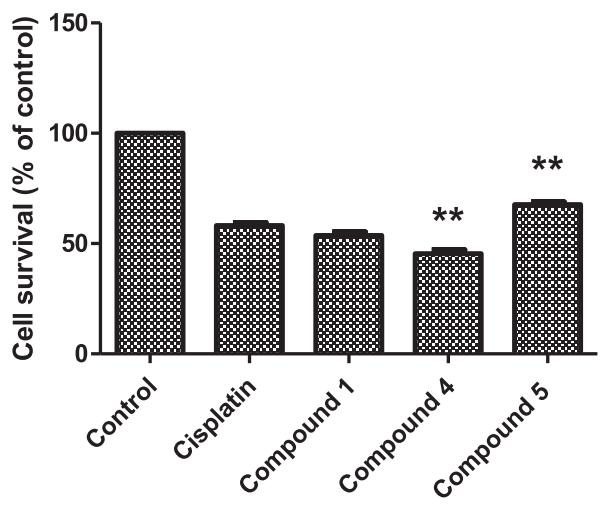

Fig. 2. Cytotoxic effect of cisplatin and compounds 1, 4 ve 5 against A549. Compound 4 and $\mathbf{5}$ significantly different from respective cisplatin ${ }^{* *} p<0.05$.

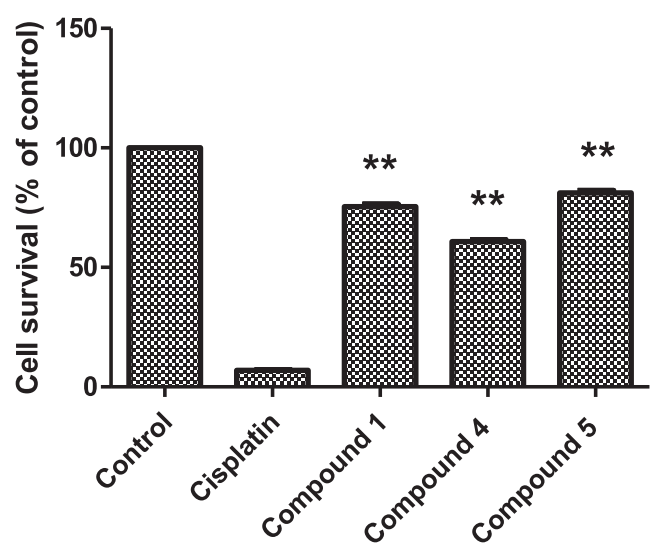

Fig. 3. Cytotoxic effect of cisplatin and compounds $\mathbf{1}, \mathbf{4}$ and $\mathbf{5}$ against BEAS-2B. Compound 1, 4 and $\mathbf{5}$ significantly different from respective cisplatin ${ }^{* *} p<0.05$.

Table 2

In vitro antimicrobial activities MIC data $(\mu \mathrm{g} / \mathrm{mL})$ of benzimidazole - $\mathrm{Co}(\mathrm{II})$ and $\mathrm{Zn}(\mathrm{II})$ complexes.

\begin{tabular}{llllll}
\hline Compounds & E. coli & S. aureus & P. aeruginosa & E. faecium & C. albicans \\
\hline $\mathbf{1}$ & 25 & 6,25 & 200 & 12,5 & 6,25 \\
$\mathbf{2}$ & 200 & 6,25 & 400 & 100 & 100 \\
$\mathbf{3}$ & 100 & 6,25 & 400 & 100 & 50 \\
$\mathbf{4}$ & 50 & 6,25 & 200 & 50 & 12,5 \\
$\mathbf{5}$ & 50 & 6,25 & 200 & 25 & 12,5 \\
$\mathbf{6}$ & 100 & 6,25 & 400 & 200 & 100 \\
$\mathbf{7}$ & 100 & 6,25 & 400 & 200 & 100 \\
$\mathbf{8}$ & 100 & 6,25 & 200 & 200 & 100 \\
$\mathbf{9}$ & 200 & 6,25 & 400 & 400 & 200 \\
$\mathbf{1 0}$ & 100 & 6,25 & 400 & 400 & 200 \\
$\mathbf{1 1}$ & 200 & 6,25 & 400 & 200 & 200 \\
$\mathbf{1 2}$ & 100 & 6,25 & 400 & 100 & 400 \\
$\mathbf{1 3}$ & 50 & 6,25 & 400 & 100 & 400 \\
$\mathbf{1 4}$ & 50 & 6,25 & 400 & 200 & 400 \\
Ciprofloksasin & $<0,039$ & $<0,039$ & $<0,039$ & $<0,039$ & \\
Gentamisin & $<0,024$ & $<0,024$ & $<0,024$ & $<0,024$ & \\
Fluconazole & & & & & $<0,024$ \\
\hline
\end{tabular}

activity to the compounds [56]. Some compounds are more effective than the others. The compounds, especially 1, 4 and 5 which have high antimicrobial activity against all the microorganisms, also showed low cytotoxicity against healthy human lung bronchial epithelium cells (BEAS-2B). Because of their low cytotoxic effects against healthy cells these compounds may be a potential as an antimicrobial agent.

\section{Conclusions}

The synthesis and cytotoxic activity of fourteen benzimidazole derivatives have been reported in this work. The cytotoxic activities of the new benzimidazole metal complexes on human cancer cells (A549) and normal cells (BEAS-2B) have been evaluated. It can be concluded from our result that compounds 1, 4 and 5 are more cytotoxic on A549 cells than cisplatin. On the other hand cisplatin has higher cytotoxicity on BEAS-2B cells than the compounds. These compounds are also effective antimicrobial agents. In conclusion, result of this work has encouraged us to investigate their anticancer profiles in further studies.

\section{Declaration of interest}

The authors declare no conflicts of interest. 


\section{Acknowledgements}

The authors would like to thank the financial support from The Scientific and Technological Research Council in Turkey (TUBITAK) (Grant no: 113Z647). We would like to thank Assist. Prof. Harika Gozukara Bag (Inonu University, Medical Faculty, Department of Biostatistics, Malatya/Turkey) and Ayla Burcin Asutay (Yeditepe University, Department of Genetics and Bioengineering, Istanbul/ Turkey) for helping about statistical analysis and sending the A549 cells, respectively.

\section{References}

[1] W.A. Denny, G.W. Rewcastle, B.C. Baguley, J. Med. Chem. 33 (1990) 814.

[2] S. Demirayak, U.A. Mohsen, A.C. Karaburun, Eur. J. Med. Chem. 37 (2002) 255.

[3] P.S. Sharma, R. Sharma, R. Tyagi, Curr. Cancer Drug Targets 8 (2008) 53.

[4] D. Carcangue, Y.K. Shue, M.A. Wuonola, M.U. Nickelsen, C. Joubran, J.K. Abedi, J. Jones, T.C. Kuhler, J. Med. Chem. 45 (2002) 4300.

[5] P. Lindberg, P. Nordberg, T. Alminger, A. Bradstrom, B. Wallmark, J. Med. Chem. 29 (1986) 1327.

[6] D. Olander, J. Zwawiak, V. Lukianchuk, R. Lesyk, A. Kropacz, A. Fojutowski, L. Zaprutko, Eur. J. Med. Chem. 44 (2009) 645.

[7] H. Küçükbay, B. Durmaz, Arzneim. Forsch. Drug Res. 47 (1997) 667.

[8] T. Fekner, J. Gallucci, M.K. Chan, J. Am. Chem. Soc. 126 (2004) 223.

[9] H. Küçükbay, E. Çetinkaya, R. Durmaz, Arzneim. Forsch. Drug Res. 45 (1995) 1331.

[10] R. Durmaz, M. Köroğlu, H. Küçükbay, I. Temel, M.K. Özer, M. Refiq, E. Çetinkaya, B. Çetinkaya, S. Yoloğlu, Arzneim. Forsch. Drug Res. 48 (1998) 1179.

[11] H. Zarrinmayeh, A.M. Nunes, P.L. Ornstein, D.M. Zimmerman, B. Arnold, D.A. Schober, S.L. Gackenheimer, R.F. Bruns, P.A. Hipskind, T.C. Britton, B.E. Cantrell, D.R. Gehlert, J. Med. Chem. 41 (1998) 2709.

[12] R. Medzhitov, Cell 140 (2010) 771.

[13] S. Grivennikov, F.R. Greten, M. Karin, Nature 420 (2002) 846.

[14] B.N. Cronstein, G. Weissmann, Annu. Rev. Pharmacol. Toxicol. 35 (1995) 449.

[15] J. Singh, P. Grover, D.P. Pathak, Acta Pharma. Sci. 52 (2010) 511.

[16] P. Gupta, S. Hameed, R. Jain, Eur. J. Med. Chem. 39 (2004) 805.

[17] R.V. Shingalapur, K.M. Hosamani, R.S. Keri, Eur. J. Med. Chem. 44 (2009) 4244.

[18] P. Jyoti, T.K. Vinod, V.S. Shyam, C. Vinita, S. Bhatnagar, S. Sinha, A.N. Gaikwad, R.P. Tripathi, Eur. J. Med. Chem. 44 (2009) 3350.

[19] F. Hadizadeh, H. Hosseinzadeh, V. Sadat Motamed-Shariaty, M. Seifi, S. Kazemi, Iran. J. Pharm. Res. 7 (2008) 29.

[20] P. Naik, P. Murumkar, R. Giridhar, M.R. Yadav, Bioorg. Med. Chem. 18 (2010) 8418.

[21] K. Kubo, Y. Inada, Y. Kohara, Y. Sugiura, M. Ojima, K. Itoh, Y. Furukawa, K. Nishikawa, T. Nakat, J. Med. Chem. 36 (1993) 1772.

[22] N.H. Hauel, H. Nar, H. Priepke, U. Ries, J.M. Stassen, W. Wienen, J. Med. Chem. 45 (2002) 1757.

[23] A.R. Porcari, R.V. Devivar, L.S. Kucera, J.C. Drach, L.B. Townsend, J. Med. Chem. 41 (1998) 1252.

[24] M. Roth, M.L. Morningstar, P.L. Boyer, S.H. Hughes, R.W. Buckheit Jr., C.J. Michejda, J. Med. Chem. 40 (1997) 4199.

[25] I.S. Ahuja, I. Prasad, Inorg. Nucl. Chem. Lett. 12 (1976) 777.

[26] E. Lukevics, P. Arsenyan, I. Shestakova, I. Domracheva, A. Nestrova, O. Pudova, Eur. J. Med. Chem. 36 (2001) 507.
[27] J.G. Lee, J.H. Shin, H.S. Shim, C.Y. Lee, D.J. Kim, Y.S. Kim, K.Y. Chung, Respir. Res 16 (2015) 138.

[28] A.S. Yurdakul, C. Kocaturk, H. Bayiz, S. Gursoy, A. Bircan, A. Ozcan, A. Akkoclu, F. Uluorman, P. Celik, D. Koksal, B. Ulubas, E. Sercan, O. Ozbudak, T. Goksel, T. Onalan, E. Yamansavci, F. Turk, G. Yuncuk, C. Copuraslan, T. Mardal, E. Tuncay, A. Karamustafaoglum, P. Yildiz, F. Secik, M. Kaplan, E. Caglar, M. Ortakoylu, M. Onal, A. Turna, E. Hekimoglu, L. Dalar, S. Altin, M. Gulhan, E. Akpinar, I. Savas, N. Firat, G. Camsari, G. Ozkan, E. Cetinkaya, E. Kamiloglu, B. Celik, Y. Havlucu, Cancer Epidemiol. 39 (2015) 216.

[29] E. Giannopoulou, A. Nikolakopoulos, D. Kotsirilou, A. Lampropoulou, S. Raftopoulou, E. Papadimitriou, A.D. Theocharis, T. Makatsoris, K. Fasseas, H.P. Kalofonos, Serb. Chem. Soc. 73 (2008) 1153.

[30] D.J. Clark, Y. Mei, S. Sun, H. Zhang, A.J. Yang, L. Mao, Theranostics 6 (2016) 65.

[31] A.K. Farha, S.R. Dhanya, S. Nair Mangalam, P. Remani, Nat. Prod. Res. 29 (2015) 2341.

[32] M.Y. Ahn, T.H. Kim, S.M. Kwon, H.E. Yoon, H.S. Kim, J.I. Kim, Y.C. Kim, K.W. Kang, S.G. Ahn, J.H. Yoon, Eur. J. Pharm. Sci. 79 (2015) 122.

[33] G. Greve, I. Schiffmann, M. Lübbert, J. Cancer Res. Clin. Oncol. 141 (2015) 2171.

[34] M.L. Katherine, Y. Bharadwaj, T.K. Eckols, M. Kolosovb, M.M. Kasembelib, C. Fridleyc, R. Sillerb, D.J. Tweardy, Lung Cancer 90 (2015) 182.

[35] J. Zhao, W. Fu, H. Liao, L. Dai, Z. Jiang, Y. Pan, H. Huang, Y. Mo, S. Li, G. Yang, J. Yin, BMC Cancer 15 (2015) 731.

[36] N. Sireci, H. Küçükbay, M. Akkurt, S.P. Yalçın, M.N. Tahir, H. Ott, J. Coord. Chem. 63 (2010) 3218.

[37] N. Şireci, Ü. Yılmaz, H. Küçükbay, M. Akkurt, Z. Baktır, S. Türktekin, O. Büyükgüngör, J. Coord. Chem. 64 (2011) 1894.

[38] H. Küçükbay, Ü. Yılmaz, M. Akkurt, O. Büyükgüngör, Turk. J. Chem. 39 (2015) 108.

[39] H. Küçükbay, A. Mumcu, S. Tekin, S. Sandal, Turk. J. Chem. 40 (2016) 393.

[40] S. Türktekin, M. Akkurt, E. Orhan, F.Z. Küçükbay, H. Küçükbay, O. Büyükgüngör, Acta Cryst. Sec. E E60 (2004) m1220.

[41] L.J. Mathias, D. Burkett, Tetrahedron Lett. 49 (1979) 4709.

[42] T.P. Filipskikh, A.F. Pozharskii, V.N. Koroleva, A.M. Simonov, E.A. Zvezdina, Khimiya Geterotsiklicheskikh Soedin. 6 (1972) 809.

[43] A.A. Nikitenko, G. Khafizova, J.L. Gross, PCT Int. Pat. Syst. (2010) 2010009029

[44] Q.Q. Xia, W.Z. Chen, H.Y. Qiu, C.-N. Direct, J. Org. Chem. 76 (2011) 7577.

[45] Y.Q. Wan, C. Wallinder, B. Plouffe, H. Beaudry, A.K. Mahalingam, A. Karlen, A. Pettersson, F. Nyberg, L. Fandriks, N. Gallo-Payet, A. Hallberg, M. Alterman, J. Med. Chem. 47 (2004) 5995.

[46] V. Vasantha, A.S. Jana, A. Parthiban, J.G. Vancso, Chem. Commun. 50 (2014) 46.

[47] N.A. Demarse, S. Ponnusamy, E.K. Spicer, E. Apohan, J.E. Baatz, B. Ogretmen, C. Davies, J. Mol. Biol. 394 (2009) 789.

[48] A.A. Gokbulut, E. Apohan, Y. Baran, Hematology 18 (2013) 144.

[49] H. Wu, J. Yuan, Y. Bal, G. Pan, H. Wang, J. Shao, J. Gao, Y. Wang, J. Coord. Chem. 65 (2012) 4327.

[50] M. Poyraz, M. Sarı, A. Güney, F. Demirci, Ş. Demirayak, E. Şahin, J. Coord. Chem. 61 (2008) 3276

[51] L. Yurttas, S. Demirayak, G.A. Ciftci, S.U. Yıldırım, Z.A. Kaplancıklı, Arch. Pharm. Life Sci. 346 (2013) 403.

[52] S. Liu, W. Cao, L. Yu, W. Zheng, L. Linlin, C. Fan, T. Chen, Dalton Trans. 42 (2013) 5932.

[53] K. Blaszczak-Swiatkiewicz, P. Olszewska, E. Mikiciuk-Olasik, Pharmacol. Rep. 66 (2014) 100.

[54] A. El-Serif, J. Solut. Chem. 39 (2010) 1562.

[55] P.O. Asekunowo, R.A. Haque, M.R. Razali, S. Budagupi, Appl. Organometal. Chem. 29 (2015) 126.

[56] V.M. Podunavac-Kuzmanovic, D.D. Leovac, J. Cvetkovic, Serb. Chem. Soc. 73 (2008) 1153. 